\title{
Analisis Semantik Kata Dla'îf dalam Surah An-Nisa Ayat 28 dan Surah Ar-Rum Ayat 54
}

\author{
Karunia Kholifah Dini Agustin \\ Universitas Islam Negeri Maulana Malik Ibrahim Malang \\ Corresponding author: karuniakholifahdini@gmail.com
}

\section{Abstract}

God created human beings along with their diverse traits and characters which have pivotal roles in driving them to do selfreflection to become better human beings blessed by God. In the Qur'an, Allah not only described the good characters and personalities that humans had, but also the bad ones hated by Him. The purpose of this research was to further reveal the meaning of Annisa verse 28 and Ar-rum verse 54 to avoid any mistakes in the interpretation of word dla îf located in different surah. This type of research was descriptive qualitative with literature review data collection techniques. Data analysis was conducted by reducing data, presenting it and drawing conclusions. From the results of this study, it was found that in the Qur'an there were many terms or words that were the same but had different meanings as was the case with the word dla'îf in Annisa verse 28 and Ar-rum verse 54. In Surah Annisa the word dlaîf was interpreted as a mental sate of faint-hearted person, whereas in surah Ar-rum was interpreted as a human weakness in terms of both physical and non-physical condition. The absence of balance in humans' life can drive them to behave badly.

Allah menciptakan Manusia dengan berbagai sifat, dari sifat-sifat tersebut niscaya agar manusia mengintropeksi diri sehingga menjadi manusia yang lebih baik dan dicintai Allah. Allah tidak hanya menggambarkan sifat baik yang dimiliki manusia tetapi juga menggambarkan sifat buruk manusia yang tidak disukai Allah didalam al Qur'an. Penelitian ini diadakan dengan tujuan agar mengetahui lebih mendalam makna yang terkandung secara utuh dari surah An-nisa ayat 28 dan surah Ar-rum ayat 54 dan agar tidak

ISSN 2622-6146 (e) 2622-6138 (p)

(c) Alsina : Journal of Arabic Studies

http://journal.walisongo.ac.id/index.php/alsina 
ada kesalahan dalam memaknai makna yang terkandung pada kata dla'îf yang terdapat dalam surah yang berbeda. Jenis penelitian ini adalah deskriptif kualitatif dengan teknik pengumpulan data pustaka. Analisa data dilakukan dengan mereduksi data, penyajian data dan penarikan kesimpulan. Dari hasil penelitian ini ditemukan bahwa dalam Alqur'an banyak terdapat istilah-istilah atau kata-kata yang sama akan tetapi mempunyai makna yang berbeda seperti halnya dengan kata dari kata dla'if dalam surah Annisa ayat 28 dan surah Arrum ayat 54. Dalam surah annisa kata dla'îf dimaknai sifat manusia yang lemah hati, sedangkan dla'îf dalam surah Arrum dimaknai sebagai sifat manusia yang lemah dari segi fisik maupun nonfisik. Ketidak sesuaian dalam menjalani fase kehidupan tersebut dapat mengakibatkan pada perilaku sesorang menjadi jelek atau buruk.

Keywords: analisis; dla'îf; ilm al-dalalah; semantik.

\section{Pendahuluan}

Tidak ada keraguan lagi, bahwa Alqur'an adalah kalam Allah yang tertulis yang isi didalamnya mengandung dasar-dasar ajaran islam, karena seluruh yang tertulis dan termaktub dalam Alqur'an dijadikan pedoman hidup bagi manusia dan juga dapat memberikan petunjuk agar mendapatkan kebahagiaan hidup didunia dan akhirat. Supaya bisa memahami kandungan makna dalam Alqur'an maka seseorang tidak akan dapat memahaminya apabila hanya dengan membaca dan mengiramakannya dengan baik tanpa berusaha untuk mengetahui makna dari apa yang dibaca. Penting bagi ummat Islam untuk mengetahui, memahami dan menghayati kandungan makna isi ayatayat yang terdapat dalam Alqur'an, hal ini mengingat bahwa Alqur'an merupakan pedoman hidup bagi ummat Islam.

Sebagian orang beranggapan bahwa arti dan makna merupakan kata yang besinonim. Hal ini bisa dilihat dari pengertian "arti" yang terdapat dalam Kamus Besar Bahasa Indonesia (KBBI) yang mana makna adalah maksud dari penulis, arti yang memperlihatkan makna yang terdapat pada tulisan kuno, 
dan pengertian yang diberikan kepada suatu bentuk kebahasaan ${ }^{1}$. Tetapi ditinjau dari sudut pandang Linguistik bahwa arti dan makna merupakan suatu istilah yang berbeda karena apabila arti dasar itulah yang disebut sebagai arti sedangkan makna itu adalah arti yang berubah dari bentuk dasarnya. Misalnya kata "mata" yang berartikan indra yang digunakan untuk melihat lain halnya dengan kata "mata keranjang" yang menunjukkan perubahan arti kata dasar yang bermakna seorang playboy, arti baru inilah yang disebut dengan makna ${ }^{2}$.

Nilai-nilai moral yang terdapat dalam Alqur'an yang tersebar dalam segala bentuk kandungannya seperti kisah-kisah sejarah ummat masa lalu, hukum-hukum syari'ah baik berupa muamalah, ibadah, dan aqidah. Apabila diteliti lebih jauh ternyata jumlah ayat makkiyah dalam Alqur'an adalah 4780 ayat, berarti tiga perempat atau sebagian dari isi Alqur'an pada umumnya mengandung penjelasan tentang perbuatan baik dan jelek dan keimanan. Pahala yang dijanjikan untuk orang yang berbuat baik dan beriman, dan ancaman untuk orang yang berbuat jahat dan yang tidak percaya, riwayat dari ummat terdahulu dan teladan serta ibarat yang dapat diambil dari pengalaman-pengalaman mereka ${ }^{3}$. Untuk memahami dan mendalami makna dari kandungan nilai-nilai tersebut maka diperlukan ilmu dilalah.

Manusia diciptakan dengan keanekaragaman sifat yang melekat dalam dirinya. Sifat-sifat tersebut juga telah Allah sebutkan dalam KalamNya, tak hanya satu melainkan banyak dari sifat-sifat manusia yang Allah sebutkan dalam Al-Qur'an.

1 Depertemen Pendidikan dan Kebudayaan, Kamus Besar Bahasa Indonesia, (Jakarta: Balai Pustaka, 1995) hal 619

2 Sahkholid Nasution, Pengantar Linguistik Bahasa Arab, (Malang: Lisan Arabi, 2017) hal 149

${ }^{3}$ Harun Nasution, Akal dan Wahyu dalam Islam, (Jakarta : Universitas Indonesia Press, 1986) hal 26-27 
Diantara sifat-sifat tersebut antaranya adalah Sifat Dhaif (Lemah), Dhalim (Dholim) ,Yaisun (Putus Asa), Nisyan (Pelupa), Khouf (Penakut) dan lain sebagainya. Dari beberapa sifat yang sudah disebutkan, maka dalam pembahasan ini, penulis akan memfokuskan sifat dla îf manusia yang terkandung dalam surah An-Nisa ayat 28 dan surah Ar-rum ayat 54. Dipilihnya kata dla'îf karena kebanyakan orang mengartikan kata tersebut dengan "lemah" tanpa memahami perbedaan makna yang tergandung di surah yang berbeda dari sudut pandang semantik. Pembahasan ini dirasa sangat penting untuk mengetahui lebih dalam makna yang terkandung secara utuh dari surah An-nisa ayat 28 dan surah Ar-rum ayat 54 dan juga penting untuk dikaji karena para mufassir atau pakar tafsir qur'an pun tidak bisa lepas dari sentuhan semantik.

\section{Metode}

Dengan mempertimbangkan pembahasan dan tema yang diangkat maka penelitian ini menggunakan metode deskriptif dengan jenis penelitian kualitatif deskriptif yang mana dalam penelitiannya lebih memfokuskan pada pengkajianpengkajian terhadap teks. Data yang diambil bersumber dari data primer yaitu Al-Qur'an, yang mana digunakan untuk menelusuri kata dla'îf pada ayat-ayat yang ada didalam Alqur'an. Dan untuk sumber data pendukungnya adalah buku tafsir yang ditulis mufassir untuk dapat membantu dalam menganalisis ayat-ayat alqur'an yang dimaksud. Teknik pengumpulan datanya dilakukan dengan study pustaka yaitu dengan cara mengkaji dokumen atau teks yang berhubungan dan berkaitan dengan pokok pembahasan dengan mengumpulkan data penelitian kemudian data yang telah terkumpul selanjutnya di olah dan di analisis kemudian membuat kes- 
impulan dari teori-teori yang terkumpul dan kemudian dianalisis. Penulis menganalisis menggunakan berbagai referensi umtuk menggungkap makna yang sempurna yang terkandung dalam ayat-ayat tentang dlaîf.

\section{Pengertian Semantik}

Secara etimologi, "semantik" (bahasa Indonesia) di serap dari bahasa Inggris, yaitu "semantics" yang berarti studi tentang makna (meaning: Inggris). Dalam beberapa literatur berbahasa Arab disiplin ilmu ini disebut dengan berbagai istilah, yaitu: " علم المعنى " d " علم الدلالة" dahkan disebut "سيمانتك"; sebagai kata pungutan dari bahasa Inggris (semantics) atau Prancis (semantique). Isitilah semantik pertama sekali muncul pada tahun 1883 M. oleh ilmuan Prancis yang bernama Breal, melaui artikelnya yang diberi judul: "Le Lois Intellectuelles du Language ${ }^{\prime \prime}$.

Semantik dianggap sebagai salah satu bagian terpenting dalam linguistik karena dalam study yang mengkaji tentang makna mengalami kemajuan yang sangat pesat seperti fonologi, morfologi dan sintaksis. Semantik secara bahasa diambil dari bahasa yunani semantike yang artinya tanda ( sedangkan secara istilah menurut Mishel Zakariyah semantik adalah tataran deskriptif atau salah satu tingkatan dalam bahasa yang mengkaji apa saja yang terkait dengan makna. Seperti, pembahasan tentang perkembangan makna kemudian mengkomparasikan dengan bidang-bidang semantik ${ }^{5}$.

Definisi semantik menurut Umar :

${ }^{4}$ Sahkholid Nasution, Pengantar Linguistik Bahasa Arab......., hal 147

5 Mohammad. Kholison, Semantik Bahasa Arab, (Sidoarjo : CV.Lisan Arabi, 2016) hal 6 


$$
\begin{aligned}
& \text { انه "دراسة المعنى " أو "العلم الذي يدرس المعنى" أو "ذلك الفرع }
\end{aligned}
$$

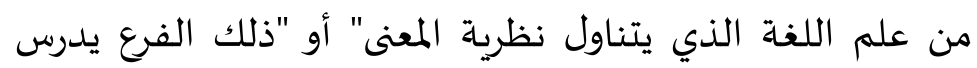

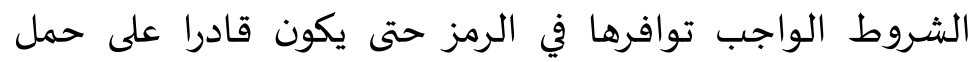

$$
\begin{aligned}
& \text { المعنى" المن }
\end{aligned}
$$

a) Semantik adalah ilmu yang membahas makna atau studi tentang makna

b) Cabang linguistik yang objek kajiannya terfokus pada teori tentang makna

c) Cabang linguistik yang mengkaji syarat-syarat yang harus dipenuhi oleh suatu simbol hingga menyandang makna

Banyak yang menganggap antara kata dan makna adalah istilah yang bersinonim yang tidak ada perbedaan antara keduanya, akan tetapi dalam kajian linguistik kata dan makna merupakan istilah yang berbeda. Dalam bahasa arab arti disebut المعنى sedangkan makna disebut atau diterjemahkan dengan Sahkholid mengkutip ungkapan Nasution Lyons dalam Djajasudarma, bahwa memberikan atau mengkaji kata adalah mendalami dan memahami lebih dalam kata tersebut yang berkenaan dengan hubungan-hubungan makna yang membuat kata tersebut berbeda antara kata satu dengan kata lain. Arti dalam hal ini menyangkut makna leksikal dari kata-kata itu sendiri ${ }^{7}$.

Tak diragukan lagi bahwa bahasa merupakan rangkaian dari kata yang mengandung makna didalamnya dan merujuk kepada objek tertentu. Karena itu maka dalam memahami dan mengungkapkan makna kata tersebut diperlukan suatu metode metode sehingga dapat menghasilkan pemahaman

${ }^{6}$ Mohammad Kholison,......, hal 6

7 Sahkholid Nasution, ......hal 149 
yang sempurna terhadap rangkaian kata yang berbentuk ucapan maupun tulisan.

Al-Qur'an merupakan wahyu yang Allah turunkan dengan bahasanya yang indah dan mengandung banyak pengetahuan didalamnya. Manusia tidak akan mampu memahami kandungan pengetahuan yang terdapat dalam Al-Qur'an jika tidak mengetahui bahasa Al-Qur'an itu sendiri. ${ }^{8}$ Untuk itu Amin Al Khulli menjelaskan, salah satu cara memahami kandungan isi didalam Al-Qur'an adalah dengan melakukan studi aspek internal Al-Qur'an. Studi ini mencakup perkembangan makna dan signifikasi kata-kata tertentu dalam Al-Qur'an dalam bentuk tunggalnya. Kemudian melihat indikasi makna dalam berbagai generasi serta pengaruhnya secara psikologi sosial dan peradaban umat terhadap pergeseran makna.

\section{Jenis-jenis Makna}

Menurut Verhar, ada dua jenis makna yaitu makna leksikal dan makna gramatikal :

1. Makna Leksikal

Menurut Djadjasudarma, makna leksikal adalah makna unsur-unsur bahasa sebagai lambang benda, peristiwa, dan lain-lain ${ }^{9}$. Pengertian ini mengarah pada makna-makna kata yang ada dalam kamus, karena itu makna leksikal juga sering disebut sebagai makna kamus yaitu makna yang dapat dilacak didalam kamus. Makna leksikal memikili karakteristik yang dapat membedakan dari makna-makna yang lain :

a) Makna leksikal melekat pada kata-kata yang berada dalam kamus, atau makna kata-kata pada waktu berdiri sendiri baik dalam bentuk tuturan maupun dalam bentuk dasar.

\footnotetext{
${ }^{8}$ M.yusron Dkk, Studi Kitab Tafsir Kontemporer, (Yogyakarta : Teras, 2006) hal 18

${ }^{9}$ Djadjasudarma \& T. Fatimah, Semantik I, Makna Leksikal dan Makna Gramatikal, (Bandung : Refika Aditama,2009) hal 16
} 
b) Makna kata yang sesuai dengan referennya, meskipun kata tersebut dalam bentuk kalimat.

c) Makna leksikal bisa berada dalam struktur atau konteks kalimat, atau diluar struktur dan konteks dalam kamus

2. Makna Gramatikal

Makna gramatikal adalah makna yang menyangkut hubungan intra bahasa, Atau makna yang muncul sebagai akibat berfungsinya sebuah kata dalam kalimat. Munculnya makna gramatikal ini adalah sebagai akibat berfungsinya sebuah kata dalam konstruksi tertentu ${ }^{10}$. Kalau makna leksikal itu berkenaan dengan makna leksem atau kata yang sesuai dengan referennya, maka makna gramatikal ini adalah makna yang hadir sebagai akibat adanya proses gramatika seperti proses afiksasi, reduplikasi, dan komposisi atau kalimatisasi. Umpamanya, dalam proses afiksasi prefik ber- dengan dasar baju melahirkan makna gramatikal 'mengenakan' atau 'memakai baju'11.

\section{Relasi Makna}

Relasi makna menurut Abdul Chaer adalah hubungan semantik yang terdapat antara satuan bahasa yang satu dengan satuan bahasa yang lainnya. Satuan bahasa tersebut bisa berupa frase, kata, kalimat, dan relasi semantik itu dapat menyatakan kesamaan makna, pertentangan makna, kegandaan makna ${ }^{12}$.

\section{Perubahan Makna}

10 Muhammad kholison, Semantik Bahasa Arab,........hal 192

11 Mansoer Pateda, Semantik Leksikal, (Jakarta: Rineka Cipta, 2001 Edisi 2), hal.119

12 Abdul Chaer, Linguistik Suatu Pengantar, (Bandung: Angkasa,1993) hal.60-62 
Makna sebuah kata secara sinkronis, tidak akan berubah. Namun secara diakronis ada kemungkinan bisa berubah. Banyak faktor yang menyebabkan perubahan makna diantaranya : kebutuhan akan makna baru, perkembangan sosial budaya, penyimpangan bahasa, inovasi dan kreatifitas, perbedaan bidang pemakaian, transfer majas, asosiasi, tabu bahasa dan peralihan dari pengacuan yang konkrit menjadi abstrak ${ }^{13}$.

Dari beberapa pendapat mengenai perubahan makna yang disebabkan oleh beberapa faktor, makna dapat berubah tergantung bagaimana suatu makna tersebut dibutuhkan di beberapa kondisi tertentu. Karena ketika kita seang membicarakan tentang makna, orang tidak akan melepaskan diri dari pembicaraan tentang lambang dan acuan. Bahasa yag dinamissesuai dengan sifat manusia yang dinamis. Perubahan makna yang tampak dalam kata- kata adalah akibat perkembangan kebutuhan manusia sebagai pemakai bahasa ${ }^{14}$.

Menurut Samsuri ada tiga bentuk perubahan makna, yaitu penambahan, pengurangan, dan penggantian. Berikut ini akan dijelaskan bentuk-bentuk perubahan bahasa :

1. Makna Penambahan atau Meluas ${ }^{15}$

Menurut Chaer yang dimaksud dengan perubahan makna dalam bentuk penambahan atau meluas adalah gejala yang terjadi pada sebuah kata atau leksem yang pada mulanya hanya memiliki sebuah makna, tetapi kemudian karena berbagai faktor menjadi memiliki makna makna lain. Contoh bentuk kata "saudara," pada mulanya bermakna 'seperut' atau 'sekandung' kemudian berkembang maknanya menjadi 'siapa

13 Mohammad Kholison....., hal 206

${ }^{14}$ Abdul Chaer, Pengantar Semantik Bahasa Indonesia, (Jakarta: Rineka Cipta 2013) hal.160-161

15 Abdul Chaer, Pengantar Semantik Bahasa Indonesia........., hal 141 
saja yang sepertalian darah,' akibatnya 'anak pamanpun' disebut saudara, selanjutnya siapapun yang mempunyai kesamaan asal-usul disebut juga saudara. Bahkan kini siapapun dapat disebut saudara. Seperti dalam kalimat: "Setiap orang harus menghormati saudaranya sesama manusia".

2. Makna Mengurang atau Menyempit

Menurut Chaer, yang dimaksud dengan makna mengurang/menyempit adalah gejala yang terjadi pada sebuah kata yang pada mulanya memiliki makna yang cukup luas, kemudian berubah menjadi terbatas. ${ }^{16}$ Dalam bahasa Arab, dapat dikemukakan beberapa contoh kata yang maknanya menyempit, yaitu kata "الطهارة" dimaksudkan " الختان" dan kata "الحريم" dimaksudkan "النساء".

3. Penggantian Makna atau Perubahan Total

Menurut Chaer, yang dimaksud dengan perubahan total adalah berubahnya sama sekali makna sebuah kata dari makna asalnya, walaupun kemungkinan ditemukan unsur keterkaitan antara makna asal dengan makna yang baru. ${ }^{17}$

\section{Hasil dan Pembahasan}

a. Pengertian Konteks Dla'îf

Secara bahasa kata dla'îf (ضعيف) berasal dari kata ( ض ع ف). Dalam Kamus Besar Bahasa Indonesia (KBBI) dla'îf atau lemah merupakan kata Adjectiva atau kata sifat yang berarti tidak bertenaga, lembut, tidak keras hati, tidak kuat, dan tidak tegas.

Ada banyak sifat manusia yang Allah gambarkan dalam AlQur'an salah satunya sifat dla'îf. Didalam Al-Qur'an kata dla'îf disebutkan didalam surah An-nisa ayat 28 dan surah Ar-rum

${ }^{16}$ Abdul Chaer, Linguistik Umum, ( Jakarta: Rineka Cipta, 1994, cet. I). hal. 142.

${ }^{17}$ Abdul Chaer, Linguistik Umum..., hal. 143 
ayat 54. Surah An-nisa tergolong pada surah Madaniyah yang mana surah tersebut berjumlah 176. Disebut surah An-nisa karena isinya lebih banyak membahas tentang hal-hal yang berhubungan dengan wanita dibandingkan surah lain, seperti halnya surah At-talaq yang juga membahas tentang tentang hal wanita maka dari itu surah At-talaq disebut sebagai surah Annisa Sughro. Sedangkan surah Ar-rum adalah surah ke 30 dalam Al-Qur'an dengan jumlah ayatnya yaitu 60 ayat dan tegolong kepada surah Makkiyah. Disebut surah Ar-rum yang berarti bangsa Romawi (Bizantium) karena dalam ayatnya menjelaskan ramalan Al-Qur'an tentang kekalahan yang berlanjut dengan kebangkitan bangsa Romawi

b. Kata Dla'îf Dalam Al-Qur'an

Banyak ayat dalam Al Qurán yang menyebutkan kata dhaif dengan berbagai derivasinya, yaitu:

1. Q.S. Annisa ayat $28^{18}$

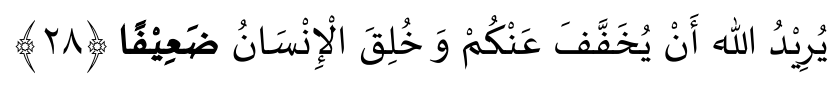

Terjemahan artinya : Allah hendak memberikan keringanan kepadamu, dan manusia dijadikan bersifat lemah.

2. Q.S. Annisa ayat $76^{19}$

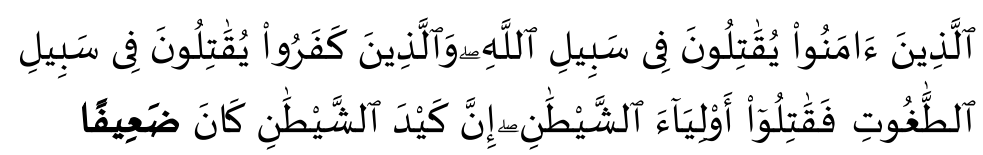

Terjemah Arti: Orang-orang yang beriman berperang di jalan Allah, dan orang-orang yang kafir berperang di

${ }^{18}$ Depertemen Agama RI, Al-Qur'an dan Terjemahnya, (Bogor : Syamil Qur'an, 2007) hal 83

19 Depertemen Agama RI , Al-Qur'an dan Terjemahnya, (Bogor : Syamil Qur'an, 2007) hal 90 
Karunia Kholifah Dini Agustin

jalan thaghut, sebab itu perangilah kawan-kawan syaitan itu, karena sesungguhnya tipu daya syaitan itu adalah lemah.

3. Q.S. Ar-rum ayat $54^{20}$

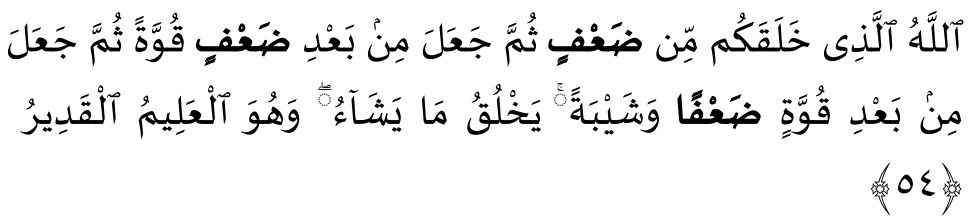

Terjemahan Arti : Allah, Dialah yang menciptakan kamu dari keadaan lemah, kemudian Dia menjadikan (kamu) sesudah keadaan lemah itu menjadi kuat, kemudian Dia menjadikan (kamu) sesudah kuat itu lemah (kembali) dan beruban. Dia menciptakan apa yang dikehendaki-Nya dan Dialah Yang Maha Mengetahui lagi Maha Kuasa.

\section{Analisis Semantik Kata Dla'îf}

1. Makna Dasar Dlaîf

Kata Dla 'îf $f$ secara umum digunakan dalam Alqur'an berarti salah satu sifat yang ada dalam diri manusia. Secara leksikal, kata dla'îf adalah bentuk isim fail dari -ضَعُفَ-ضضعف-ضعافِة . Kata dla'îf berarti lemah yang mana maksudnya adalah lemah yang mencakup dalam berbagai hal seseorang hamba. Seperti lemah kekuatan, lemah ilmu lemah badan, dan lain sebagainya. Dalam kamus Al Munawwir kata lemah tidak hanya diterjemahkan dengan kata dla'îf melainkan dengan beberapa kata yang lain juga seperti wahinun, shukhfun, adzun.(2007: 509)

2. Makna Relasional.

a) Analisis Sintagmatik

1) Dla'îf yang bermakna Lemah dengan godaan

20 Depertemen Agama RI , Al-Qur'an dan Terjemahnya, (Bogor : Syamil Qur'an, 2007) hal 410 
Dla îf yang bermakna Lemah dengan godaan disebutkan dalam Q.S. Annisa ayat 28. ${ }^{21}$ menurut Thawus rahimahullah , "hal yang disebutkan adalah mengenai wanita". Sebagaimana diriwayatkan dari Ibnu Abbas radhiallahu 'anhu bahwanya beliau membaca [وَخَلَقَ الْإِنََْانَ ضَعِيفًا] yaitu, tidak sabar terhadap [godaan] wanita". Ditafsirkan demikian karena ayat sebelumnya menjelaskan tentang motivasi menikah. ${ }^{22}$ Sebagaimana perkataan Ibnu Asyur :

$$
\text { لأن من الأحكام المتقدمة ما هو ترخيص في النكاح }
$$

"Karena hukum-hukum yang dibahas sebelumnya adalah memurahkan (mahar) pernikahan.

Jika merujuk pada kamus, maka makna dhaif dalam $\mathrm{Al}$ Qur'an tersebut sama dengan makna yang dijumpai dalam kamus munawwir (997: 822 ), yakni berartikan lemah.

Berdasarkan uraian diatas maka golongan yang dikatakan lemah adalah golongan laki-laki yang tidak dapat menahan akan godaan wanita, hal ini semakin menguatkan hati manusia bahwa mereka membutuhkan Allah Swt. Pada ayat itu, manusia itu dinyatakan sebagai mahluk yang tidak berdaya. Mereka adalah mahluk lemah. Hati manusia itu akan lemah ketika kesenangannya terhadap dunia kian bertambah. Hati yang lemah ini akan mudah jatuh pada perbuatan yang melanggar tuntunan Allah Swt. Kelemahan ini mebutuhkan kekuatan agar manusia bisa hidup dengan lebih mudah.

2) Dla'îf bermakna lemah dalam fisik

Dla'îf bermakna lemah dalam fisik disebutkan dalam Q.S. Ar-Rum ayat 54 . Berdasarkan ayat tersebut, Allah membagi

21 Al-Jami' liahkamil Quran 5/149, Darul Kutub Al-mishriyah,(Kairo:cetakan kedua Asy-Syamilah)

${ }^{22}$ At-Tahrim Wat Tanwir 5/22 
fase manusia dalam 3 tahap. Ibn Katsir di dalam Tafsirnya menjelaskan tentang ayat ini,

"Kemudian ia keluar dari rahim ibunya, lemah, kurus, dan tak berdaya. Kemudian ia tumbuh sedikit demi sedikit sampai ia menjadi seorang anak, lalu ia mencapai usia baligh, dan setelahnya menjadi seorang pemuda, yang merupakan kekuatan setelah kelemahan. Kemudian ia mulai menjadi tua, mencapai usia paruh baya, lantas menjadi tua dan uzur, kelemahan setelah kekuatan, maka ia kehilangan ketetapan hati, tenaga untuk bergerak, serta kemampuan berperang, rambutnya menjadi kelabu dan sifat-sifatnya, zahir dan batin, mulai berubah."

Kata dla'îf $\mathrm{pada}$ ayat ini mengandung makna bahwa setiap manusia akan berada pada titik kelemahan dalam segi fisik. Karna dari awal penciptaan manusia Allah sudah memberikan pengetahuan yang tertulis didalam Al-Qur'an bahwasannya manusia pasti mempunyai kelemahan atau sifat lemah dari segi fisik maupun nonfisik.

b) Analisis Paradigmatik

1) Lemah menurut Keadaan seorang ibu

Sebagaimana disebutkan dalam Q.S. Al-Lukman ayat 14 :

Terjemah Arti: Dan Kami perintahkan kepada manusia (berbuat baik) kepada dua orang ibu-bapaknya; ibunya telah mengandungnya dalam keadaan lemah yang bertambah-tambah, dan menyapihnya dalam dua tahun. Bersyukurlah kepada-Ku dan kepada dua orang ibu bapakmu, hanya kepada-Kulah kembalimu²3.

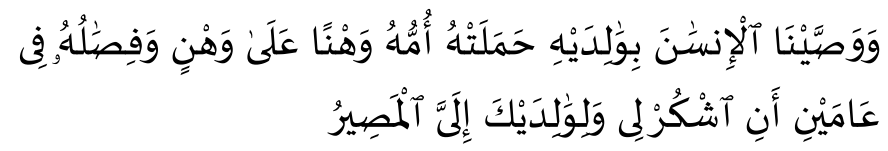

23 Depertemen Agama RI , Al-Qur'an dan Terjemahnya, (Bogor : Syamil Qur'an, 2007) hal 412 
Berdasarkan ayat diatas, maksud dari "ibunya telah mengandungnya dalam keadaan lemah yang bertambah-tambah" adalah seorang perempuan adalah makhluk yang lemah kemudian bertambah lemah ketika dalam keadaan mengandung

2) Dhaif Tipu daya setan

Dhaif Tipu daya setan disebutkan dalam Q.S. Annisa ayat 76. ${ }^{24}$ Dalam satu ayat Allah menyebutkan bahwa manusia itu lemah, kemudian dalam ayat ini Allah pun menyebutkan ten-

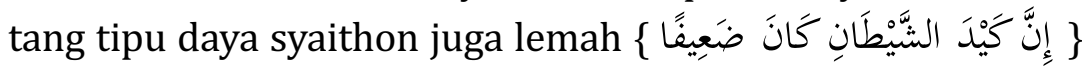
dan dua makhluk yang lemah ini ketika bertemu dalam peperangan, lalu setiap dari keduanya tidak memiliki penolong, maka itulah Allah memeritahkan manusia yang lemah ini untuk mememohon pertolongan kepada tuhan yang Maha Lembut agar mereka dijauhkan dari tipu daya syaithon yang lemah.

Dari penjelasan diatas kata dla'îf dalam Al-Qur'an terkadang mempunyai makna yang sama terkadang juga berbeda tergantung kepada konteks bawaannya. Pada kata dla'îf yang terdapat dalam 2 surah yang berbeda mengandung makna yang berbeda pula. Perubahan makna yang terjadi antara surah An-nisa dan surah Ar-rum disebabkan karna perbedaan dalam penggunaannya dan juga bentuk dari perluasaan makna.

\section{Kesimpulan}

Didalam Alqur'an terdapat kata-kata atau istilah-istilah yang sama dalam bentuk penulisan akan tetapi mempunyai arti dan makna yang berbeda. Pun sebaliknya terdapat istilahistilah berbeda tetapi mengandung arti dan makna yang sama.

${ }^{24}$ Syaikh Dr. Muhammad Sulaiman Al Asyqar, mudarris tafsir Universitas Islam Madinah 
Setiap istilah dalam Alqur'an penting untuk dipahami secara benar agar tidak salah dalam memaknai makna yang terkandung didalamnya. Seperti halnya hasil temuan dari penelitian ini yaitu perubahan makna kata dla îf yang terkandung dalam surroh Annisa ayat 28 dan kata dla'îf dalam surah Arrum ayat 54 yang mana keduanya mempunyai kata yang sama dengan makna yang berbeda dalam penerapannya. Dalam surah Annisa kata dla'îf mengandung makna sifat yang dimiliki seorang laki-laki yang lemah terhadap godaan wanita, sedangkan makna kata dla'îf yang terkandung dalam alqur'an surroh Arrum ayat 54 adalah suatu tahapan manusia yang awalnya diciptakan pada fase atau kondisi lemah seperti balita dan pada akhirnya akan dikembalikan ke pada fase lemah. Dan ketidaksesuaian dalam penempatan fase-fase tersebut akan berdampak pada perilaku seseorang menjadi buruk. Dalam hal ini kata dla'îf mengalami perubahan makna karena perluasan makna yang terkandung didalam ayat tersebut.

\section{Referensi}

Al-Jami'liah kamil Quran 5/149, Darul Kutub Al-mishriyah. Kairo:cetakan kedua Asy-Syamilah)

Chaer, Abdul dan Liliana Muliastuti, Semantik Bahasa Indonesia, PBIM 4215, Modul 1

Chaer, Abdul. (1993). Linguistik Suatu Pengantar, Bandung: Angkasa

Chaer, Abdul. (2013) . Pengantar Semantik Bahasa Indonesia, Jakarta: Rineka Cipta

Chaer, Abdul .(1994). Linguistik Umum. Jakarta: Rineka Cipta cet. I 
Depertemen Agama RI .(2007). Al-Qur'an dan Terjemahnya. Bogor : Syamil Qur'an,

Depertemen Pendidikan dan kebudayaan. (1995). Kamus Besar Bahasa Indonesia, Jakarta: Balai Pustaka,

Djadjasudarma \& T. Fatimah. (2009). Semantik I, Makna Leksikal dan Makna Gramatikal, Bandung : Refika Aditama

Kholison, Mohammad. (2016). Semantik Bahasa Arab. Sidoarjo : CV.Lisan Arabi

Munawwir, Ahmad Warson. (1997). Kamus Al-munawwir Arab-Indonesia Terlengkap. Surabaya : Pustaka Progressif cetakan ke empat belas

Munawwir, Ahmad Warson. (2007). Kamus Almunawwir Indonesia-Arab. Surabaya : Pustaka Progressif cetakan pertama

M.yusron Dkk,. (2006). Studi Kitab Tafsir Kontemporer. Yogyakarta : Teras

Nasution, Harun. (1986). Akal dan Wahyu dalam Islam. Jakarta :Universitas Indonesia Press

Nasution, Sahkholid. (2017). Pengantar Linguistik Bahasa Arab. Malang: Lisan Arabi

Pateda, Mansoer. (2001). Semantik Leksikal. Jakarta: Rineka Cipta Edisi 2

Syaikh Dr. Muhammad Sulaiman Al Asyqar, mudarris tafsir Universitas Islam Madinah (https://tafsirweb.com/7418-quran-surat-ar-rum-ayat-54.html) 
